\title{
Tenure Audit, Reputasi Auditor dan Kualitas Audit pada Perusahaan Manufaktur : Analisis Kompleksitas Operasi sebagai Pemoderasi
}

\author{
Amirul Hadi Khasani ${ }^{1}$, Amilin ${ }^{2}$, Choirul Anwar ${ }^{3}$ \\ ${ }^{1}$ Universitas ... \\ ${ }^{2}$ Universitas Islam Negeri Syarif Hidayatullah Jakarta \\ ${ }^{3}$ Universitas Negeri Jakarta
}

INFO ARTIKEL

JEL Classsification:

M42

M41

G02

Keywords:

audit quality, audit

tenure, auditor

reputation, complexity

of operations

\section{ABSTRACT}

This study examines the influence of audit tenure and auditor reputation on audit quality with operational complexity as a moderating variable. The Enron case involving Arthur Andersen led to the limitation of the audit tenure. Audit quality is measured by current accrual while audit lag is measured by calculating the year in which the same auditor has committed to the auditee, the auditor's reputation is measured by the peer group amount and the operating complexity is measured using the number of subsidiaries. This study focused on manufacturing companies listed on the Indonesia Stock Exchange 2011 to 2015, using purposive sampling method obtained 225 research samples. Hypothesis testing in this study using multiple regression analysis. Test results show that audit tenure does not affect audit quality, auditor reputation does not affect audit quality while operating complexity affects on tenure audit relationship with audit quality and auditor reputation with audit quality.

\begin{abstract}
ABSTRAK
Penelitian ini menguji pengaruh tenure audit dan reputasi auditor terhadap kualitas audit dengan kompleksitas operasi sebagai variabel moderasi. Kasus Enron yang melibatkan Arthur Andersen menyebabkan pembatasan tenure audit. Kualitas audit diukur dengan akrual lancar sedangkan tenure audit diukur dengan menghitung tahun dimana auditor yang sama telah melakukan perikatan dengan auditee, reputasi auditor diukur dengan menggunakan kelompok jumlah rekan dan kompleksitas operasi diukur dengan menggunakan jumlah anak perusahaan. Penelitian ini difokuskan pada perusahaan manufaktur yang terdaftar di Bursa Efek Indonesia tahun 2011 sampai dengan 2015, dengan menggunakan motode purposive sampling diperoleh 225 sampel penelitian. Pengujian hipotesis dalam penelitian ini menggunakan analisis regresi berganda. Hasil pengujian menunjukkan bahwa tenure audit tidak berpengaruh terhadap kualitas audit, reputasi auditor tidak berpengaruh pada kualitas audit sedangkan kompleksitas operasi berpengaruh pada hubungan tenure audit dengan kualitas audit dan reputasi Auditor dengan kualitas audit.
\end{abstract}

*Email Korespondensi: ' amirulhadi79@gmail.com, 


\section{Pendahuluan}

Dalam suatu perusahaan, laporan keuangan memiliki peran dan fungsi yang sangat penting baik internal maupun eksternal. Untuk mempertahankan kualitas dalam laporan keuangan, peran auditor sangat diperlukan untuk menjembatani antara kepentingan pihak prinsipal dengan pihak agen, yaitu manajer sebagai pengelola keuangan perusahaan. Tujuan audit atas laporan keuangan oleh auditor independen pada umumnya adalah untuk menyatakan pendapat tentang kewajaran, dalam semua hal yang material, posisi keuangan, hasil usaha, perubahan ekuitas, dan arus kas sesuai dengan prinsip akuntansi yang berlaku umum di Indonesia. Oleh sebab itu kualitas audit sangat dibutuhkan untuk memberikan opini yang berkualitas.

Masalah Enron di Amerika Serikat membuat banyak pihak terkejut, apalagi hal tersebut melibatkan salah satu Kantor Akuntan Publik (KAP) internasional yakni Arthur Andersen (AA). Banyak pihak menempatkan auditor sebagai pihak yang paling bertanggung jawab terhadap masalah ini. Independensi auditor merupakan salah satu faktor yang diduga memicu masalah ini (Giri, 2010). Perikatan audit yang dilakukan AA sudah hampir 20 tahun, seharusnya AA banyak mengetahui mengenai kliennya. Kondisi tersebut menimbulkan tanda tanya dan diduga bahwa tugas audit yang terlalu lama dilakukan seorang auditor maupun KAP menyebabkan keterikatan secara emosional dan menurunkan independensinya. Keraguan lainnya yang muncul mengenai reputasi auditor yang yang berkaitan dengan sikap independensi dalam menghasilkan kualitas audit yang tinggi.

Kasus mirip Enron kembali terjadi lagi di India. Kali ini perusahaan yang terlibat adalah Satyam Computer Sevices Ltd. dengan KAP Pricewaterhouse \& Cooper (PwC). Pada tanggal 9 April 2015 pengadilan Hyderabad menjatuhkan putusan kepada sepuluh terdakwa kasus fraud satyam. Dua diantara sepuluh terdakwa tersebut adalah mantan patner PwC. Kedua mantan partner PwC tersebut didakwa ikut bertanggung jawab terhadap manipulasi laporan keuangan Satyam karena tidak mengetahui adanya fraud dalam laporan keuangan Satyam yang telah diaudit PwC selama delapan tahun.

Sikap independensi auditor yang rendah membuka peluang klien melakukan kecurangan akuntansi. Hal ini disebabkan karena eskalasi komitmen dari auditor untuk selalu memberikan pendapat wajar terhadap laporan keuangan klien yang menyimpang. Eskalasi komitmen ini terkait dengan tindakan low-balling untuk memperoleh pendapatan di masa yang akan datang (Moore et al. 2006 dalam Giri 2010).

Audit merupakan suatu cara akuntan untuk menyelesaikan masalah manipulasi akuntansi, walaupun tingkat audit yang optimal tidak diketahui namun tampaknya hal tersebut belum tercapai sehingga usahausaha untuk meningkatkan kualitas audit terus dilakukan (Baridwan dan Hariani, 2010). Levitt (1998) dalam Baridwan dan Hariani (2010) menganjurkan berbagai perbaikan audit dalam keprihatinannya terhadap manipulasi akuntansi. Usaha peningkatan kualitas audit ini dilakukan dengan mensyaratkan pendidikan minimum per tahun, membatasi masa perikatan (tenur) auditor dengan kliennya, serta membentuk komite audit (Baridwan dan Hariani, 2010).

Perlu disadari bahwa kualitas audit sangat penting, namun permasalahan yang ada sampai saat ini adalah menentukan tinggi rendahnya kualitas audit, yakni menemukan metode yang handal untuk mengukur kualitas audit secara akurat (Wibowo dan Rossieta, 2009). Menurut Wibowo dan Rossieta (2009) salah satu metode handal dengan proksi yang terukur adalah dengan menggunakan informasi dari laporan audit dan laporan keuangan, seperti yang dilakukan oleh Carey dan Simnett (2006).

Giri (2010) menyatakan bahwa KAP bereputasi menjelaskan adanya sikap independensi auditor dalam melaksanakan tugas audit. KAP besar identik dengan KAP bereputasi tinggi dalam hal ini menunjukkan 
kemampuan auditor untuk bersikap independen dalam melaksanakan audit secara professional, sebab KAP menjadi kurang tergantung secara ekonomi kepada klien. Klien juga kurang dapat mempengaruhi opini auditor. Penyebab dari hal tersebut adalah kelebihan yang dimiliki oleh KAP besar yaitu besarnya jumlah dan ragam klien yang ditangani KAP, banyaknya ragam jasa yang ditawarkan, adanya afiliasi internasional, dan banyaknya jumlah staf audit dalam suatu KAP.

Studi mengenai kualitas audit telah dilakukan baik di luar maupun di dalam negeri seperti penelitian yang dilakukan oleh Carey dan Simnett (2006) membuktikan bahwa tenur audit yang panjang berhubungan negatif terhadap kualitas audit. Myers et al (2003) menemukan bahwa tenur berpengaruh negatif terhadap akrual diskretioner, hasil ini juga didukung oleh penelitian Manry et al (2008). Lim dan Tan (2009) menemukan bahwa kualitas audit meningkat sesuai dengan peningkatan tenur auditor pada perusahaan yang diaudit oleh auditor spesialis tetapi tidak pada perusahaan yang diaudit bukan oleh auditor spesialis.

Penelitian di dalam negeri mengenai kuaitas audit dilakukan oleh Wibowo dan
Rossieta (2009) yang meneliti mengenai faktorfaktor determinasi kualitas audit, suatu studi dengan pendekatan earning surprise benchmark menemukan bahwa size KAP dan regulasi secara signifikan berpengaruh positif terhadap kualitas audit sedangkan masa penugasan (audit tenur) tidak berpengaruh terhadap kualitas audit. Sukriah (2009) menemukan bahwa pengalaman kerja, objektivitas dan kompetensi berpengaruh positif terhadap kualitas hasil pemeriksaan. Baridwan dan Hariani (2010) meneliti tentang insentif untuk memanipulasi laba sebagai syarat keefektifan audit yang berkualitas dalam mengurangi manipulasi laba menemukan bahwa audit yang berkualitas lebih efektif dalam mengurangi manipulasi akuntansi daripada yang kurang berkualitas hanya bila ada insentif untuk memanipulasi laba terlebih dahulu. Penelitian lainnya dilakukan oleh Giri (2010) yang meneliti mengenai pengaruh tenur kantor akuntan publik (KAP) dan reputasi KAP terhadap kualitas audit: kasus rotasi wajib auditor di indonesia, hasil penelitiannya menunjukkan bahwa tenur panjang auditor berpengaruh negatif terhadap akrual lancar yang artinya bahwa semakin lama tenur auditor akan semakin tinggi kemampuan auditor membatasi tindakan akrual oleh manajemen.

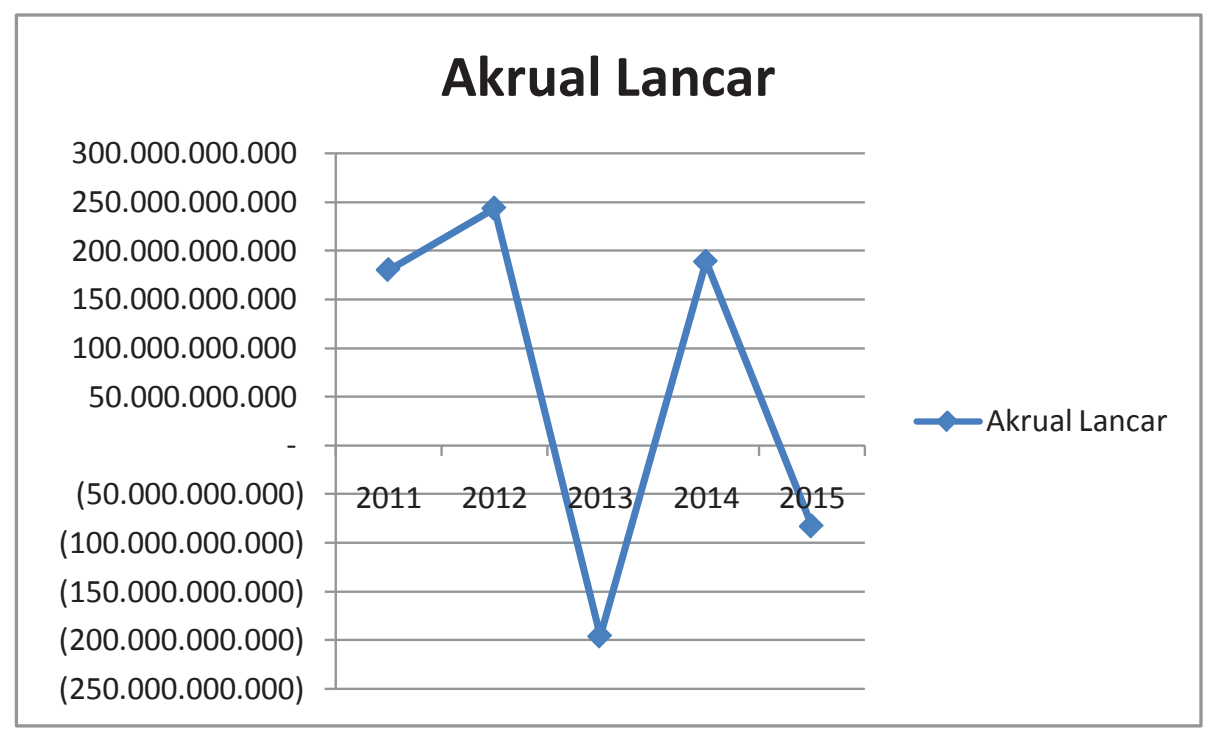

Sumber: data diolah 2017

\section{Gambar 1. Grafik Rata-rata Nilai Akrual Lancar Perusahaan Manufaktur yang terdaftar di BEI periode 2011 - 2015}


Gambar 1 menunjukkan bahwa nilai akrual lancar perusahaan manufaktur yang terdaftar di BEI periode 2011-2015 mengalami fluktuasi. Terlihat pada tahun 2012 terjadi peningkatan nilai akrual lancar yang berarti audit yang dilakukan pada perusahaan manufaktur pada tahun 2012 mengalami penurunan kualitas audit dibanding tahun sebelumnya. Sedangkan pada tahun 2013 terjadi penurunan nilai akrual lancar yang berarti terjadi peningkatan kualitas audit pada tahun 2013. Pada tahun 2014 lagilagi nilai akrual lancar meningkat yang artinya kualitas audit yang dilakukan pada tahun 2014 mengalami penurunan dan pada tahun 2015 memperlihatkan peningkatan kembali kualitas audit yang ditunjukkan dengan menurunnya nilai akrual lancar dibandingkan tahun sebelumnya. Kondisi tersebut di atas membuat peneliti tertarik untuk meneliti kualitas audit dengan menggunakan proksi akrual lancar.

Penelitian ini berbeda dengan penelitian sebelumnya. Objek penelitian sebelumnya adalah Perusahaan Manufaktur yang terdaftar di Bursa Efek Indonesia tahun 1996-2005 dan tahun penelitian 2010, perbedaan lainnya adalah ukuran variabel Reputasi KAP pada penelitian sebelumnya menggunakan variabel dummy dengan melihat ada tidaknya afiliasi dengan KAP Big Four sedangkan pada penelitian ini diukur berdasarkan jumlah rekan KAP dan pada penelitian ini ada tambahan variabel moderasi yaitu kompleksitas operasi.

Penelitian ini masih penting untuk dilakukan karena kegagalan KAP mendeteksi kecurangan masih terjadi dan hasil penelitianpenelitian sebelumnya tidak konsisten. Ketidakkonsistenan yang terjadi pada hasil penelitian-penelitian sebelumnya antara lain penelitian yang dilakukan oleh Giri (2010) dengan populasi perusahaan manufaktur yang terdaftar di BEI dari tahun 1996-2005 menemukan bahwa tenur audit berpengaruh positif pada kualitas audit sedangkan Mgbame et al (2012) yang melakukan penelitian di Nigeria dengan menggunakan proksi the big five auditors dan Nadia (2015) dengan populasi penelitian perusahaan manufaktur yang terdaftar di BEI tahun 2008-2012 menemukan bahwa tenur audit berpengaruh negatif pada kualitas audit, Wahono dan Setyadi (2014) dengan objek penelitian perusahaan manufaktur sektor industri barang konsumsi yang terdaftar di BEI pada tahun 2011-2013 menemukan bahwa tenur KAP tidak berpengaruh positif terhadap kualitas audit, Junaidi dkk (2014) dengan sampel penelitian perusahaan manufaktur yang terdaftar di BEI dari tahun 2002-2010 menemukan bahwa tenur audit tidak berpengaruh pada kualitas audit, dan Fitriany dkk (2015) dengan sampel penelitian perusahaan-perusahaan yang terdaftar di BEI selama periode sebelum regulasi rotasi audit yaitu tahun 1999-2001 dan periode paska regulasi yaitu tahun 2004-2008 menemukan bahwa pada periode sebelum regulasi tenure audit tidak signifikan mempengaruhi kualitas audit, tetapi setelah periode regulasi tenure audit memiliki hubungan convex dengan kualitas audit. Ketidakkonsistenan hasil penelitianpenelitian tersebut menyebabkan isu ini menjadi topik yang penting untuk diteliti.

\section{Telaah Teori dan Pengembangan Hipotesis}

\section{Hubungan antara tenure audit dan kualitas audit}

Tenure adalah jangka waktu perikatan yang terjalin antara KAP dengan auditee yang sama. Terdapat sejumlah studi yang berusaha menghubungkan antara kualitas audit dengan masa penugasan audit. DeAngelo (1981) dalam Wibowo dan Rossieta (2009) melakukan penelitian terkait dengan kualitas audit berdasarkan teori permintaan dan penawaran kualitas jasa audit. Argumen utamanya adalah permintaan (dan penawaran) kualitas jasa audit dapat terpenuhi dengan semakin panjangnya masa penugasan auditor (auditor tenure), karena auditor dapat terus menggunakan teknologi dan pengetahuan audit yang telah diperoleh selama menjalankan audit pada periode sebelumnya dan 
memberikan jasa secara konsisten.

Wibowo dan Rossieta (2009) mengatakan bahwa lamanya masa penugasan audit dapat meningkatkan kualitas audit dengan berbagai alasan. Pertama, biaya audit yang tinggi (termasuk diantaranya kegagalan audit) diasosiasikan dengan periode awal masa penugasan audit dengan argumen bahwa walaupun tingkat independensi auditor relatif lebih tinggi diawal masa penugasan, namun tingkat familiaritasnya lebih rendah, terlihat dari tingginya tingkat kegagalan audit pada masa awal tersebut. Argumen kedua yang mendukung sisi positif lamanya penugasan audit mengatakan bahwa pengetahuan tentang klien dan industri yang diperoleh setelah audit berulang-ulang akan meningkat, sehingga meningkatkan kualitas audit.

Chi dan Huang (2005) dalam Wibowo dan Rossieta (2009) melakukan pengujian di Taiwan dan menemukan bukti bahwa kualitas laba klien lebih rendah pada periode awal penugasan audit, yang berlaku baik bagi hasil audit oleh Akuntan Publik maupun Kantor Akuntan Publik. Namun peningkatan kualitas laba dalam masa penugasan audit yang lebih lama hanya berlaku pada KAP. Dalam studi ini, kualitas laba diukur dengan tingkat abnormal accruals, dimana kualitas laba yang rendah diartikan sebagai kualitas audit yang rendah, karena auditor membiarkan terjadinya praktek manajemen laba.

Myers et al (2003) memperoleh hasil bahwa tenur berpengaruh negatif terhadap akrual diskresioner yang dapat diartikan bahwa semakin lamanya masa penugasan maka semakin tingginya kualitas audit, hasil ini juga sesuai dengan penelitian yang dilakukan oleh Ghosh dan Moon (2005). Penelitian Manry et al (2008) juga menemukan bahwa tenur auditor berhubungan negatif dengan discretionary accruals yang dapat diartikan kualitas audit meningkat sesuai dengan peningkatan tenur. Giri (2010) memandang bahwa tenur audit yang panjang akan mendorong terciptanya pengetahuan bisnis bagi seorang auditor.
Pengetahuan ini dapat digunakan untuk merancang program audit yang efektif dan menciptakan laporan keuangan yang berkualitas tinggi. Jika dilihat dari hasil penelitian dan alasan logis yang disampaikan terkait dengan hubungan tenur dan kualitas audit, maka dapat dimunculkan satu proposisi bahwa kualitas audit akan semakin tinggi ketika tenur auditor semakin lama. Berdasarkan proposisi ini dapat disusun hipotesis sebagai berikut:

$\mathrm{H}_{1}$ : Tenure audit berpengaruh positif terhadap kualitas audit.

\section{Hubungan antara reputasi auditor dan kualitas audit}

Giri (2010) menyatakan KAP besar identik dengan KAP bereputasi tinggi. Ukuran KAP juga menunjukkan kemampuan auditor untuk bersikap independen dan melaksanakan audit secara profesional, sebab KAP menjadi kurang tergantung secara ekonomi kepada klien. Klien juga kurang dapat mempengaruhi opini auditor.

Wibowo dan Rossieta (2009) menyebutkan dibandingkan dengan KAP kecil, KAP besar mempunyai kemampuan yang lebih baik dalam melakukan audit, sehingga mampu menghasilkan kualitas audit yang lebih tinggi. Hal tersebut karena KAP besar mempunyai kelebihan yaitu (i) besarnya jumlah dan ragam klien yang ditangani KAP; (ii) banyaknya ragam jasa yang ditawarkan; (iii) luasnya cakupan geografis, termasuk adanya afiliasi international; dan (iv) banyaknya jumlah staf audit dalam suatu KAP. Berdasarkan argumen tersebut maka hipotesis kedua yang diajukan adalah sebagai berikut,

$\mathrm{H}_{2}$ : Reputasi auditor berpengaruh positif terhadap kualitas audit.

Hipotesis $\mathrm{H}_{2}$ diterima apabila koefisien reputasi bertanda negatif dan signifikan terhadap variabel akrual lancar.

\section{Hubungan tenure audit, kompleksitas operasi, dan kualitas audit}

Kompleksitas operasi merupakan akibat dari pembentukan departemen dan pembagian 
pekerjaan yang memiliki fokus terhadap jumlah unit yang berbeda. Ketergantungan yang semakin kompleks terjadi apabila organisasi dengan berbagai jenis atau jumlah pekerjaan dan unit menimbulkan masalah manajerial dan organisasi yang lebih rumit (Martius, 2012:12). Semakin besar tingkat kompleksitas opersi perusahaan maka semakin tinggi pula tingkat kompleksitas audit yang harus dihadapi oleh auditor. Peningkatan kompleksitas dalam suatu tugas membuat tingkat keberhasilan tugas itu menurun. Dalam kegiatan pengauditan, kompleksitas audit yang tinggi membuat akuntan berperilaku disfungsional sehingga menyebabkan penurunan kualitas audit (Restu dan Indriantoro, 2000 dalam Ratha dan Ramantha, 2015). Penelitian Andin Prasita dan Priyo Hari (2007) mengenai Pengaruh Kompleksitas Audit dan Tekanan Anggaran Waktu terhadap Kualitas Audit dengan Moderasi Pemahaman terhadap Sistem Informasi. Hasil penelitian menunjukkan bahwa kompleksitas audit dan tekanan anggaran waktu mempunyai pengaruh negatif terhadap kualitas audit. Sehingga hal tersebut juga mempengaruhi ketepatan waktu penyampaian laporan keuangan perusahaan kepada publik. Hubungan tersebut juga didukung oleh penelitian Ashton et.al (1987) dalam Ariyani dan Trisna (2014) yang menemukan bahwa terdapat hubungan positif antara kompleksitas operasi perusahaan dengan audit delay. Apabila dikaitkan dengan hubungan tenure dan kualitas audit dimana seharusnya semakin lama masa perikatan auditor dengan klien akan menyebabkan kualitas audit menjadi semakin baik karena pengetahuan auditor tentang klien dan industri akan semakin meningkat seiring dengan lamanya masa penugasan, tetapi seiring lamanya masa penugasan auditor menyebabkan adanya kedekatan antara auditor dengan manajemen perusahaan yang dapat merusak independensi auditor. Berdasarkan argumen tersebut maka hipotesis kedua yang diajukan adalah sebagai berikut:

$\mathrm{H}_{3}$ : Kompleksitas operasi mampu memoderasi pengaruh tenure audit terhadap kualitas audit.

\section{Hubungan antara reputasi auditor, kompleksitas operasi, dan kualitas audit}

Tingkat kompleksitas operasi sebuah perusahaan yang bergantung pada jumlah dan lokasi unit operasinya (cabang) serta diversifikasi jalur produk dan pasarnya, lebih cenderung mempengaruhi waktu yang dibutuhkan auditor untuk menyelesaikan pekerjaan auditnya. Semakin besar tingkat kompleksitas opersi perusahaan maka semakin tinggi pula tingkat kompleksitas audit yang harus dihadapi oleh auditor. Peningkatan kompleksitas dalam suatu tugas membuat tingkat keberhasilan tugas itu menurun. Dalam kegiatan pengauditan, kompleksitas audit yang tinggi membuat akuntan berperilaku disfungsional sehingga menyebabkan penurunan kualitas audit (Restu dan Indriantoro, 2000 dalam Ratha dan Ramantha, 2015). Penelitian Andin Prasita dan Priyo Hari (2007) mengenai Pengaruh Kompleksitas Audit dan Tekanan Anggaran Waktu terhadap Kualitas Audit dengan Moderasi Pemahaman terhadap Sistem Informasi. Hasil penelitian menunjukkan bahwa kompleksitas audit dan tekanan anggaran waktu mempunyai pengaruh negatif terhadap kualitas audit. Sehingga hal tersebut juga mempengaruhi ketepatan waktu penyampaian laporan keuangan perusahaan kepada publik. Wibowo dan Rossieta (2009) menyebutkan dibandingkan dengan KAP kecil, KAP besar mempunyai kemampuan yang lebih baik dalam melakukan audit, sehingga mampu menghasilkan kualitas audit yang lebih tinggi.

Berdasarkan argumen tersebut maka hipotesis keempat yang diajukan adalah sebagai berikut:

$\mathrm{H}_{4}$ : Kompleksitas operasi mampu memoderasi pengaruh reputasi auditor terhadap kualitas audit.

\section{Metode Penelitian}

Penelitian ini dilakukan di Bursa Efek Indonesia (BEI) melalui Indonesian Capital Market Directory (ICMD). Selain melalui ICMD 
penelitian ini juga dilakukan dengan mengakses langsung ke situs Bursa Efek Indonesia yakni www.idx.co.id, sedangkan objek penelitian yang digunakan dalam penelitian ini adalah perusahaan manufaktur yang terdaftar di Bursa Efek Indonesia periode tahun 2011-2015. Penelitian ini menggunakan data sekunder, yaitu data yang dikumpulkan dan dipublikasikan oleh pihak lain. Data sekunder yang dipakai dalam penelitian ini diperoleh dari Indonesian Capital Market Directory (ICMD), dan laporan tahunan yang diterbitkan oleh perusahaan serta profil perusahaan tercatat yang diperoleh dari situs www.idx.co.id. Pengambilan sampel dilakukan dengan metode nonprobability sampling yang dalam hal ini adalah metode purposive sampling yaitu teknik pengambilan sampel berdasarkan kriteria tertentu. Adapun kriteria pemilihan sampel dalam penelitian ini adalah sebagai berikut.

1) Perusahaan manufaktur selain sektor industri barang konsumsi yang terdaftar berturut-turut di Bursa Efek Indonesia pada periode 2011-2015.

2) Menerbitkan laporan keuangan auditan secara lengkap (laporan auditor independen, neraca, laporan laba rugi, laporan arus kas, perubahan ekuitas dan catatan atas laporan keuangan) dengan periode berakhir 31 Desember tahun 2011-2015.

3) Menerbitkan laporan keuangan dengan menggunakan mata uang Rupiah.

4) Semua sampel yang diperoleh sesuai dengan regulasi.

Berdasarkan metode ini, diperoleh 225 sampel pengamatan yang memenuhi kreteria seperti yang telah disebutkan dengan rincian sebagai berikut.

Tabel 1. Daftar Rincian Sampel

\begin{tabular}{lc}
\hline \multicolumn{1}{c}{ Keterangan } & $\begin{array}{c}\text { Jumlah Sampel } \\
\text { Pengamatan }\end{array}$ \\
\hline Perusahaan manufaktur yang terdaftar berturut-turut di Bursa & 128 \\
Efek Indonesia pada periode 2011-2015. & -32 \\
Perusahaan manufaktur sektor industri barang konsumsi. & -51 \\
Tidak menerbitkan laporan keuangan dengan mata uang Rupiah dan tidak & \\
menerbitkan laporan keuangan auditan secara lengkap (laporan auditor & \\
independen, neraca, laporan laba rugi, laporan arus kas, perubahan ekuitas & \\
dan catatan atas laporan keuangan) dengan periode berakhir 31 Desember & \\
tahun 2011-2015. & 45 \\
Jumlah perusahaan manufaktur yang menjadi sampel. & $\mathbf{2 2 5}$ \\
Jumlah sampel penelitian (45 x 5) & \\
\hline
\end{tabular}

Sumber: data diolah

Berdasarkan pokok permasalahan yang telah dirumuskan diatas, maka variabel-variabel yang dianalisis dalam penelitian ini adalah sebagai berikut. Variabel dependen adalah variabel yang dipengaruhi atau yang menjadi akibat karena adanya variabel bebas (Sugiyono, 2012). Variabel dependen dalam penelitian ini adalah kualitas audit. Variabel independen adalah variabel yang mempengaruhi atau yang menjadi sebab perubahannya atau timbulnya variabel dependen atau terikat (Sugiyono, 2012). Variabel independen dalam penelitian ini adalah tenure audit dan reputasi auditor. Variabel moderasi adalah variabel yang mempengaruhi (memperkuat atau memperlemah) hubungan antara variabel bebas dengan variabel terikat (Sugiyono, 2012). Variabel moderasi dalam penelitian ini adalah kompleksitas operasi. 
Tenure Audit adalah masa jangka waktu perikatan yang terjalin antara KAP dengan auditee yang sama. Tenure Audit diukur dengan menghitung tahun dimana KAP yang sama telah melakukan perikatan dengan auditee dalam batas regulasi yang telah ditentukan oleh pemerintah. Reputasi Auditor dalam penelitian ini diukur dengan menggunakan kelompok berdasarkan jumlah rekan KAP. Giri (2010) mengatakan bahwa KAP besar identik dengan KAP bereputasi tinggi. Reputasi Auditor diukur dengan menggunakan kelompok jumlah rekan, yaitu diberikan nilai 1 jika KAP memiliki jumlah rekan 1 s.d. 5, nilai 2 jika KAP memiliki jumlah rekan 6 s.d. 10, nilai 3 jika KAP memiliki jumlah rekan 11 s.d. 15, nilai 4 jika KAP memiliki jumlah rekan 16 s.d. 20, dan nilai 5 jika KAP memiliki jumlah rekan lebih dari 20. Semakin banyak jumlah rekan maka bisa dibilang reputasi auditor semakin tinggi karena dengan banyak rekan maka akan semakin banyak kesempatan untuk berdiskusi antara sesama rekan dalam memecahkan kasuskasus audit dan menjaga standar pengendalian mutu audit sehingga kualitas auditnya semakin tinggi dan semakin dipercaya oleh masyarakat. Kompleksitas operasi perusahaan adalah tingkat kesulitan dalam operasional suatu perusahaan, tingkat kesulitan disini dapat dilihat dari banyaknya jumlah anak perusahaan yang dimiliki oleh perusahaan induk (Innayati dan Susilowati, 2015). Jumlah anak perusahaan pada suatu perusahaan menunjukkan kompleksitas jasa audit yang diberikan oleh KAP berkaitan dengan ukuran rumit atau tidaknya transaksi yang dimiliki oleh klien KAP untuk diaudit (Widosari, 2012 dalam Innayati dan Susilowati, 2015). Kompleksitas Operasi dalam penelitian ini diukur menggunakan jumlah anak perusahaan yang dimiliki oleh perusahaan sampel. Semakin besar jumlah anak perusahaan yang dimiliki maka semakin besar pula kompleksitas operasi perusahaan tersebut. Myers et al (2003) berpendapat bahwa ukuran akuntansi akrual adalah gambaran yang masuk akal untuk kualitas audit. Pendapat tersebut diperoleh dengan menghubungkan antara kualitas laba dengan kualitas audit. Diperoleh hasil bahwa tingkat akrual yang tinggi berhubungan positif dengan auditor litigation, isu mengenai opini audit qualified, kegagalan audit dan pergantian auditor, sedangkan tingkat akrual yang rendah berhubungan dengan konservatisme auditor yang tinggi, yang dapat diusulkan sebagai tingginya kualitas audit (Myers et.al, 2003). Kualitas audit dalam penelitian ini diukur dengan menggunakan akrual lancar (current accual) sesuai dengan yang digunakan oleh Myers et.al (2003) dan Giri (2010) yang dihitung dengan menggunakan rumus sebagai berikut:

AKRUALLANCAR $=$

$(\triangle \mathrm{AL}-\Delta \mathrm{KAS})-(\Delta \mathrm{LL}-\Delta \mathrm{LJP})$

\section{Keterangan:}

$\Delta \mathrm{AL}=$ Perubahan asset lancar

$\Delta \mathrm{KAS}=$ Perubahan kas dan ekuivalen kas

$\Delta \mathrm{LL}=$ Perubahan liabilitas lancar

$\Delta \mathrm{LJP}=$ Perubahan dalam utang wesel jangka pendek dan utang jangka panjang yang akan jatuh tempo

Teknik analisis data dilakukan dengan uji regresi berganda. Pengujian regresi berganda dilakukan setelah uji asumsi klasik yang terdiri dari uji normalitas, uji multikolinearitas, uji heteroskedastisitas, dan uji autokorelasi. Uji normalitas dilakukan dengan metode uji JarqueBera dengan melihat nilai asymp.sig (2-tailed) diatas $\alpha=0.05$. Uji multikolinearitas dilakukan dengan melihat angka VIF (Variance Inflation Factor). Uji heteroskedastisitas menggunakan uji Gletjser. Uji autokorelasi menggunakan pengujian Breusch-Godfrey / BG test.

Analisis deskriptif digunakan untuk mendeskripsi variable. Uji $\mathrm{F}$ digunakan untuk melihat kelayakan model penelitian. Uji koefisien determinasi (Adjusted $\mathrm{R}$ Square) digunakan untuk mengukur seberapa jauh kemampuan model dalam menerangkan variasi variabel dependen. Pengujian hipotesis dilakukan dengan melihat hasil uji statistik t. Untuk mengetahui hasil uji $\mathrm{t}$ adalah dengan melihat hasil regresi 
yang dilakukan dengan program Eviews yaitu dengan membandingkan tingkat signifikansi masing-masing variabel bebas dengan $\alpha=0,05$. Apabila tingkat signifikansi $\mathrm{t}<\alpha=0,05$ maka $\mathrm{H} 0$ ditolak, sebaliknya jika tingkat signifikan $\mathrm{t} \geq$ $\alpha=0,05$ maka H0 diterima.

\section{Analisis Hasil dan Pembahasan}

Penelitian ini bertujuan untuk menganalisis pengaruh tenur audit, reputasi KAP terhadap kualitas audit dengan kompleksitas operasi sebagai variabel moderasi. Sampel dianalisi sejumlah 225 data perusahaan yang terdaftar di BEI tahun 2011 sampai tahun 2015.
Hasil uji asusmsi klasik menunjukkan distribusi nilai residual varibel adalah normal $(0,405>0,05)$. Hasil uji multikolinearitas menunjukkan semua nilai variabel memiliki nilai variance inflation factor $<10$. Hasil uji Gletsjer menunjukkan nilai signifikan $>0.05$ untuk seluruh pengaruh variabel independen terhadap nilai absolut residualnya. Hasil uji BreuschGodfrey/ BG test menunjukkan bahwa koefisien parameter F-statistic memberikan probabilitas signifikan 0,0824 lebih besar dari 0,05. Hal ini menunjukkan tidak adanya autokorelasi.

Deskripsi variabel penelitian dirangkum pada tabel berikut.

Tabel 2. Statistik Deskriptif

\begin{tabular}{lrrrrr}
\hline & N & Minimum & Maksimum & $\begin{array}{c}\text { Nilai Rata- } \\
\text { rata }\end{array}$ & $\begin{array}{c}\text { Standar } \\
\text { Deviasi }\end{array}$ \\
\hline Akrual Lancar & 225 & -11.338 & 8.354 & 66,65 & $1.153,66$ \\
Tenure Audit & 225 & 1 & 5 & 2,60 & 1,40 \\
Reputasi Auditor & 225 & 1 & 5 & 3,41 & 1,39 \\
Kompleksitas Operasi & 225 & 1 & 74 & 6,35 & 11,64 \\
\hline
\end{tabular}

Hasil pengujian model penelitian terangkum pada tabel berikut.

Tabel 3. Rangkuman Hasil Pengujian

\begin{tabular}{lrrrr}
\hline Keterangan & B & Std. Error & t-hitung & Sig. \\
\hline Tenur Audit & 0,289 & 0,260 & 1,110 & 0,269 \\
Reputasi Auditor & $-0,115$ & 0,251 & $-0,456$ & 0,649 \\
Tenur * Kompleksitas Operasi & $-0,286$ & 0,160 & $-1,780$ & 0,077 \\
Reputasi Auditor * Kompleksitas Operasi & 0,753 & 0,122 & 6,166 & 0,000 \\
Constant & 24,113 & 0,298 & 80,856 & 0,000 \\
R-Square & 0,366 & & & \\
Adjusted R-Square & 0,347 & & & \\
F-hitung & 19,346 & & & \\
Sig. F & 0,000 & & & \\
\hline
\end{tabular}

Hasil persamaan regresi linear berganda pada penelitian ini sebagai berikut.

$$
\ln (\mathrm{Y})=24,113+0,289 \ln (\mathrm{X} 1)-0,115 \ln (\mathrm{X} 2)-0,286 \ln \left(\mathrm{X}_{1} \cdot \mathrm{X}_{3}\right)+0,753 \ln \left(\mathrm{X}_{2} \cdot \mathrm{X}_{3}\right)+\mathrm{e}
$$

Keterangan:

$\begin{array}{lll}\mathrm{Y} & : \text { Akrual lancar } \\ \mathrm{X} 1 & : \text { Tenure } \text { audit } \\ \mathrm{X} 2 & : & \text { Reputasi Auditor } \\ \mathrm{X} 3 & : & \text { Kompleksitas operasi }\end{array}$ 
$\mathrm{X} 1 . \mathrm{X} 3$ : Interaksi tenur audit dan kompleksitas operasi

X2.X3 : Interaksi reputasi Auditor dan kompleksitas operasi

\section{Pengaruh Tenure Audit pada Kualitas Audit}

Hasil pengujian hipotesis menunjukkan bahwa tenur audit tidak berpengaruh signifikan pada kualitas audit. Hal ini berarti semakin bertambahnya masa perikatan KAP melaksanakan audit terhadap kliennya tidak akan berpengaruh terhadap kualitas auditnya. Hasil penelitian ini dapat dijadikan pertimbangan bagi regulator untuk meninjau kembali peraturan tentang pembatasan masa perikatan audit.

Bagi klien, hasil penelitian ini dapat menjadi masukan dalam mempertimbangkan keputusan pada saat akan memilih KAP yang akan bertugas mengaudit laporan keuangannya untuk tidak lagi mempertimbangkan masa perikatan audit karena tidak berpengaruh terhadap kualitas audit. Hasil penelitian ini konsisten dengan hasil penelitian Junaidi dkk (2014), Febriyanti dan Mertha (2014), dan Turel et al. (2017) yang menunjukkan bahwa tenur audit tidak mempengaruhi kualitas audit.

\section{Pengaruh Reputasi Auditor pada Kualitas Audit}

Hasil pengujian hipotesis menunjukkan bahwa reputasi auditor tidak berpengaruh secara signifikan pada kualitas audit. Hasil penelitian ini dapat menjadi informasi bagi masyarakat agar dalam menunjuk KAP tidak lagi memilih KAP berdasarkan besar atau kecilnya tetapi berdasarkan informasi kualitas auditnya. Bagi asosiasi profesi akuntan publik, penelitian ini diharapkan dapat menjadi informasi yang berguna dalam melakukan pembinaan terhadap anggota asosiasi supaya anggota tetap menjaga integritas dan independensinya dalam melaksanakan tugas audit sehingga profesi akuntan publik tetap dipercaya oleh masyarakat.
Hasil ini konsisten dengan hasil penelitian Giri (2010) yang menemukan bahwa reputasi auditor yang diukur dengan KAP yang berafilisasi dengan KAP internasional tidak berpengaruh terhadap kualitas audit dan signifikan pada level kurang dari 10 persen. Menurut Giri (2010) hasil penelitian ini bermakna bahwa berafiliasi dengan KAP internasional lebih bertujuan untuk menarik klien.

\section{Pengaruh Kompleksitas Operasi sebagai Variabel Moderasi}

Interaksi antara tenure audit dan kompleksitas operasi menunjukkan tingkat signifikansi sebesar 0,0774 lebih kecil dari 0,10 yang berarti bahwa kompleksitas operasi berpengaruh pada hubungan tenur audit dengan kualitas audit. Hasil penelitian ini dapat menjadi informasi bagi masyarakat bahwa apabila kompleksitas operasi tinggi maka auditor dengan tenur audit yang tinggi akan menghasilkan kualitas audit yang lebih baik daripada auditor dengan tenur audit rendah. Hal ini disebabkan karena auditor yang memiliki masa perikatan lama lebih menguasai proses bisnis kliennya daripada auditor baru yang perlu waktu untuk mempelajari dan memahami kegiatan bisnis kliennya. Hasil ini mendukung hipotesis yang menyatakan bahwa keberadaan kompleksitas operasi mampu memoderasi pengaruh tenure audit pada kualitas audit.

Interaksi antara reputasi auditor dan kompleksitas operasi menunjukkan tingkat signifikansi sebesar 0,000 lebih kecil dari 0,05 yang berarti bahwa kompleksitas operasi berpengaruh pada hubungan reputasi auditor dengan kualitas audit. Hasil penelitian ini menunjukkan bahwa reputasi auditor yang baik dapat dijadikan pertimbangan masyarakat dalam memilih KAP apabila kompleksitas operasi perusahaannnya tinggi. Hasil ini mendukung hipotesis yang menyatakan bahwa keberadaan kompleksitas operasi mampu memoderasi pengaruh reputasi auditor pada kualitas audit. 


\section{Simpulan, Keterbatasan dan Implikasi Hasil Penelitian}

Berdasarkan hasil penelitian yang diperoleh melalui pengujian statistik serta pembahasan yang telah diuraikan pada bab sebelumnya, maka dapat disimpulkan hal-hal sebagai berikut. Variabel tenure audit tidak berpengaruh pada kualitas audit yang berarti bahwa semakin lama KAP mengadakan perikatan audit kepada kliennya tidak menyebabkan kualitas auditnya menjadi semakin baik ataupun sebaliknya. Hasil penelitian ini tidak mendukung hipotesis. Reputasi auditor tidak berpengaruh pada kualitas audit. Hasil ini konsisten dengan hasil penelitian Giri (2010) yang menemukan bahwa reputasi auditor tidak berpengaruh terhadap kualitas audit. Hal ini mungkin disebabkan karena berafiliasi dengan KAP besar adalah lebih bertujuan untuk menarik klien. Hasil penelitian ini tidak mendukung hipotesis. Variabel interaksi tenur audit dan kompleksitas operasi berpengaruh terhadap akrual lancar. Hal ini dapat diartikan bahwa kompleksitas operasi mampu memoderasi hubungan tenur audit dengan kualitas audit. Hasil penelitian ini berhasil mendukung hipotesis. Variabel interaksi reputasi auditor dan kompleksitas operasi berpengaruh terhadap akrual lancar. Hal ini dapat diartikan bahwa kompleksitas operasi mampu memoderasi hubungan reputasi auditor dengan kualitas audit. Hasil penelitian ini berhasil mendukung hipotesis.

Beberapa keterbatasan dalam penelitian ini adalah sebagai berikut. Periode penelitian yang digunakan dalam penelitian ini yaitu lima tahun dianggap terlalu singkat. Penelitian ini hanya menggunakan sampel perusahaan manufaktur yang terdaftar di Bursa Efek Indonesia sehingga masih kurang menggambarkan kondisi perusahaan di Bursa Efek Indonesia secara keseluruhan. Proksi kualitas audit pada penelitian ini bukanlah ukuran aktual yang digunakan untuk mengukur kualitas audit. Akrual lancar sebagai proksi kualitas audit dalam penelitian ini adalah kualitas audit persepsian sehingga bukan merupakan ukuran yang akurat. Variabel moderasi yang digunakan yaitu kompleksitas operasi masih belum cukup kuat dalam memperkuat hubungan antara tenur audit dengan kualitas audit.

Beberapa saran yang dapat diajukan dalam penelitian ini adalah sebagai berikut. Menggunakan periode penelitian lebih dari lima tahun dengan waktu penelitian yang berbeda dengan penelitian ini. Sampel penelitian yang digunakan lebih bervariasi dan lebih banyak, tidak hanya perusahaan manufaktur sehingga dapat memberikan gambaran secara menyeluruh dari populasi perusahaan di Bursa Efek Indonesia. Penelitian selanjutnya dapat mempertimbangkan menggunakan proksi yang berbeda seperti menggunakan auditor spesialis industri, earnings surprise benchmark yang digunakan oleh Wibowo dan Rossieta (2009) atau dapat mempertimbangkan menggunakan kuisioner. Penelitian selanjutnya agar menggunakan variabel moderasi lainnya yang dapat lebih memperkuat hubungan antara tenur audit dengan kualits audit.

\section{Daftar Referensi}

Ariyani, D., \& Trisna, N. N. 2014. Pengaruh ProfitabilitaS, Ukuran Perusahaan, Kompleksitas Operasi Perusahaan Dan Reputasi Kap Terhadap Audit Report Lag Pada Perusahaan Manufaktur. E-Jurnal Akuntansi, 8(2), 217-230.

Baridwan, Zaki dan Hariani, Arie Rahayu. 2010. Insentif untuk manipulasi laba sebagai syarat keefektifan audit yang berkualitas dalam mengurangi manipulasi laba. www.

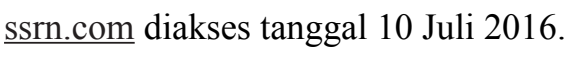

Carey, Peter. Simnett, Roger. 2006. Audit Partner Tenure and Audit Quality. The Accounting Review.

DeAngelo, L. 1981a. "Auditor Independence, „Low Ballingee, and Disclosure Regulation”. Journal of Accounting and Economics, Vol. 3, pp. 113-27. 
Febriyanti, N. M. D., \& Mertha, I. 2014. Pengaruh Masa Perikatan Audit, Rotasi KAP, Ukuran Perusahaan Klien, dan Ukuran KAP Pada Kualitas Audit.E-Jurnal Akuntansi, 7(2).

Fitriany, F., Utama, S., Martani, D., \& Rosietta, H. 2016. Pengaruh Tenure, Rotasi dan Spesialisasi Kantor Akuntan Publik (KAP) Terhadap Kualitas Audit: Perbandingan Sebelum dan Sesudah Regulasi Rotasi $K A P$ di Indonesia. Jurnal Akuntansi dan Keuangan, 17(1), 12-27.

Ghosh, Aloke. Moon, Doocheol. 2005. Auditor Tenur and Perceiptions of Audit Quality. Accounting Review, April 2005.

Giri, Efraim Ferdinan. 2010. Pengaruh Tenur Kantor Akuntan Publik (KAP) dan Reputasi KAP terhadap Kualitas Audit : Kasus Rotasi Wajib Auditor di Indonesia. Simposium Nasional Akuntansi 13.

Innayati, C. D., \& Susilowati, E. 2015. Pengaruh Karakteristik Perusahaan dan Auditor Terhadap Audit Delay (Studi Kasus Pada Perusahaan Hotel, Restoran, dan Pariwisata di Bursa Efek Indonesia). Jurnal Akuntansi., 19(3).

Junaidi, Apriyanto, H. P., Nurdiono, N., \& Suwardi, E. 2014. The effect of audit firm tenure in artificial rotation on audit quality. Journal of Economics, Business, and Accountancy| Ventura, 17(3), 439-448.

Lim, Chee-Yeow. Tan, Hun-Tong. 2009. Does Auditor Tenur Improve Audit Quality? Moderating Effects of Industry Specialization and Fee Dependence. http:// papers.ssrn.com/sol3/papers.cfm?abstract $\underline{\mathrm{id}=1638530}$, diakses tanggal 10 Februari 2016.

Manry, D. L., T.J. Mock, and J.L. Turner. 2008. Does Increased Audit Partner Tenure Reduce Audit Quality? Journal of Accounting, Auditing \& Finance: 553-572.

Martius. 2012. Anali sis Praktik Akun tansi Mana jemen Pada Peru sahaan Manu faktur
(Studi Empiris di Kawasan Industri Batam). Artikel. Program Magister Sains Akuntansi Pasca Sarjana Universitas Andalas. Padang. Mgbame, C. O., Eragbhe, E., \& Osazuwa, N. P. 2012. Audit partner tenure and audit quality: An empirical analysis. European Journal of Business and Management, 4(7), 154-162.

Myers, James N., Myers, Linda A., and Omer, Thomas C. 2003. Exploring the Term of the Auditor-Client Relationship and the Quality of Earnings: A Case for mandatory Auditor Rotation?. The Accounting Review 78(3): 779-799.

Nadia, N. F. 2015. Pengaruh Tenur KAP, ReputasiI KAP dan Rotasi KAP Terhadap Kualitas Audit. Jurnal Akuntansi Bisnis, 13(26), 113-130.

Prasita, Andin dan Priyo Hari Adi. 2007. Pengaruh Kompleksitas Audit dan Tekanan Anggaran Waktu terhadap Kualitas Audit dengan Moderasi Pemahaman terhadap Sistem Informasi, Jurnal ekonomi dan Bisnis, 13 (1).

Ratha, I., \& Ramantha, I. W. 2015. Pengaruh Due Professional Care, Akuntabilitas, Kompleksitas Audit, dan Time Budget Pressure Terhadap Kualitas Audit. E-Jurnal Akuntansi, 13(1), 311-339.

Sugiyono.2012. Metode Penelitian Bisnis. Cetakan ke 16. Bandung: Alfabeta.

Sukriah, Ika, Akram, Biana Adha Inapty. 2009. PengaruhPengalaman Kerja, Independensi, byektifitas, Integritas dan Kompetensi Terhadap Kualitas Hasil Pemeriksaan. Simposium Nasional Akuntansi 12.

Turel, A., Genç, M., Özden, B., \& Taş, N. 2017. Audit Firm Tenure and Audit Quality Implied by Discretionary Accruals and Modified Opinions: Evidence from Turkey. Acta Universitatis Danubius. Economica, 13(1).

Wahono, T.H. dan Setyadi, E.J. 2014. Pengaruh Tenur, Reputasi KAP serta Ukuran 
Jurnal Riset Akuntansi dan Perpajakan JRAP Vol. 5, No. 1, Juni 2018, hal 1-13

ISSN 2339 - 1545

Perusahaan Terhadap Kualitas Audit pada

Perusahaan Manufaktur Sektor Industri

Barang Konsumsi yang Terdaftar di BEI

Tahun 2011-2013. Kompartemen, Vol. X No.2.

Wibowo, Arie dan Rossieta, Hilda. 2009.

Faktor-Faktor Determinasi Kualitas Audit-

Suatu Studi Dengan Pendekatan Earnings

Surprise Benchmark. Simposium Nasional

Akuntansi 12. 